\title{
Factors that enhance repeat breeder condition in a crossbred dairy herd submitted to reproductive synchronization protocols
}

\section{Fatores que aumentam a condição de vacas repetidoras em um rebanho leiteiro mestiço submetido à protocolos de sincronização reprodutivos}

\author{
Fransergio SOUZA ${ }^{1}$; João CESAR ${ }^{1}$; Luisa Cunha CARNEIRO ${ }^{2}$; Ricarda Maria dos SANTOS ${ }^{1}$ \\ ${ }^{1}$ Universidade Federal de Uberlândia, Faculdade de Medicina Veterinária, Departamento de Produção Animal, Uberlândia - MG, Brazil \\ ${ }^{2}$ Universidade Estadual Paulista "Júlio de Mesquita Filho", Departamento de Medicina Veterinária Preventiva e Reprodução Animal, \\ Jaboticabal - SP, Brazil
}

\begin{abstract}
The objective of this study was to evaluate the incidence of repeat breeder (RB) in crossbred dairy cows submitted to a timed artificial insemination (TAI) and estrous synchronization protocols. Data from 371 heifers and 997 lactating crossbred dairy cows were analyzed. Cows with more than 30 DPP with good uterine condition, no lameness or clinical mastitis, and body condition score $\geq 2.5$ were used. The cows were divided between two groups, as: group 1: TAI - those cows with no CL at ultrasound exam that were enrolled in a TAI protocol and group 2: estrous synchronization - all those cows that had CL. The incidences of RB and factors relative to it were analyzed by logistic regression in SAS. The incidence of RB condition was higher in lactating cows than nonlactating heifers $(\mathrm{P}<0.001)$. There was a tendency of $\mathrm{RB}$ condition to higher in cows that calved during spring/summer than those calved at autumn/winter season. The parturition condition had no effect on RB incidence $(P>0.001)$; however, lactation degree influenced the incidence of $R B(P<0.001)$. Repeat breeder condition was greater in lactating crossbred dairy cows than in heifers. Moreover, the presence of RB cows was higher in those from second parity group when compared to those from first, third and four parity groups; on the other hand, parturition condition did not influence the appearance of RB cows in the herd.
\end{abstract}

Keywords: Fertility. Parity. Reproduction. Season.

\section{Resumo}

O objetivo deste estudo foi avaliar a incidência vacas repetidoras (VR) leiteiras mestiças submetidas à inseminação artificial em tempo fixo (IATF) e protocolos de sincronização de estro. Dados de 371 novilhas e 997 vacas leiteiras mestiças foram analisados. Vacas com mais de 30 dias pós-parto, boa condição uterina, sem mastite clínica e com escore corporal $\geq 2,5$ foram utilizadas. As vacas foram divididas em dois grupos, sendo: grupo 1: IATF - vacas sem corpo lúteo no exame ultrassonográfico e que foram submetidas ao protocolo de IATF, e grupo 2: sincronização de cio - aquelas vacas com corpo lúteo presente. A incidência de VR e seus fatores foram analisados por regressão logística pelo SAS. A incidência de VR foi maior em vacas em lactação em relação às fêmeas não-lactantes $(\mathrm{P}<$ 0,001). Ainda, uma tendência de um maior número de VR foi observada naquelas que pariram na primavera/verão quando comparadas às paridas no outono/inverno. $\mathrm{O}$ tipo de parto (normal vs. não normal) não influenciou na incidência de VR $(P>0,001)$, no entanto, foi detectado efeito do número de partos $(P>0.01)$. Dessa forma, nas categorias animais avaliadas, a incidência de VR foi maior em vacas leiteiras mestiças do que em novilhas. Uma tendência de VR foi observada naquelas que pariram na primavera/verão quando comparadas aquelas que pariram no outono/inverno, ainda a incidência de VR foi maior naquelas de segunda parição quando comparadas as de primeira, terceira ou quarta, ao passo que o tipo de parto (normal vs. não normal) não influenciou sobre a incidência de VR.

Palavras-chave: Fertilidade. Paridade. Reprodução. Estação do ano. 
Correspondence to:

Luisa Cunha Carneiro

Universidade Estadual Paulista "Júlio de Mesquita Filho",

Faculdade de Medicina Veterinária de Jaboticabal

Via de Acesso Prof. Paulo Donato Castellane, s/n

CEP 14884-900, Jaboticabal, SP, Brazil

e-mail: luisacunhacarneiro@hotmail.com

Received: $15 / 12 / 2014$

Approved: 03/10/2016

\section{Introduction}

Repeat breeder (RB) has been defined as failure to conceive from three or more regularly spaced services in the absence of detectable abnormalities, and it has long been considered as one of the most important reproductive disorders in cattle (YUSUF et al., 2010). It is still a substantial problem in cattle breeding leading to economic loss and lower profit for dairy producers, as it implies more inseminations, increases calving interval, culling rates and producers costs. (BARTLETT et al., 1986; LAFI; KANEENE, 1992).

The causes of $\mathrm{RB}$ is unclear and multifactorial (O'FARRELL et al., 1983; KIMURA et al., 1987; HEUWIESER et al., 1997; PURSLEY et al., 1998; GUSTAFSSON; EMANUELSON, 2002; MOSS et al., 2002; PÉREZ-MARÍN; ESPAÑA, 2007) indeed, the primary origin of $R B$ is really hard to define (PÉREZMARÍN; ESPAÑA, 2007).

The RB can be increased by estrus detection errors (HEUWIESER et al., 1997; PURSLEY et al., 1998), insemination of cows that are not in estrus; inflammation or anatomical impediments in the female reproductive tract, obstructed oviducts; poor oocytes; anatomical defects of reproductive tract, uterine and/or cervical/vaginal infections (PÉREZMARÍN; ESPAÑA, 2007); and subclinical endometritis (GILBERT et al., 2005; SANTOS et al., 2009).

In other studies, some authors still include different factors that can cause RB, such as quality of semen and insemination technique (HALLAP et al., 2006; MORRELL, 2006), endocrine disorders (GUSTAFSSON, 1998; BAGE et al., 2002; LÓPEZGATIUS et al., 2004), ovulation failures (KIMURA et al., 1987; BAGE et al., 2002), and early embryonic death (BAGE et al., 2002, VILLARROEL et al., 2004).

It is likely that $\mathrm{RB}$ condition consequently suffered from a temporary endocrine imbalance resulting in ovulation and fertilization failure or early embryonic loss (BULMAN; LAMMING, 1978; BAGE et al., 2002; VILLARROEL et al., 2004). So, RB may involve a combination of many factors, such as genetic factors (AYALON, 1978), abnormalities in the gametes, nutritional disorders (PETERS, 1996), even inadequate luteal function (MANN; LAMMING, 2001). It is expected that some other variables can affect the appearance of RB animals; especially those related directly to the cow, such as their parity degree, type of parturition and the season of calving.

There are many different opinions among researchers about causes of RB condition. It is clear that it involves a wide range of risk factors, some of which are very difficult to demonstrate or quantify. Most of the studies that related the incidence of $\mathrm{RB}$ were performed in dairy cattle and under different managements.

Based on that and in all those consequences that $\mathrm{RB}$ condition can bring to a system, it is evident that this condition needs to be avoided in order have a profitable herd. So, the purpose of this study was to evaluate the incidence of RB in crossbred dairy cows and heifers submitted to a timed artificial insemination protocol (TAI) and estrous synchronization and to explore some variables that could affect this condition, such as season of calving, type of calving and parity from the cows.

\section{Material and Methods}

The design of this study was approved by the Ethics Committee on the Use of Animals (CEUA) from Federal University of Uberlandia.

This study was conducted at a commercial crossbred dairy (Holstein X Gir) farm located in Centralina, Minas Gerais state, Brazil, which is a region with a warm and humid climate. The herd had 
500 lactating crossbred dairy cows, milked twice daily, and the average production was $19.50 \mathrm{~kg} / \mathrm{milk} /$ day.

During fall/winter, the animals were fed with total mixed ration based on corn silage or sorghum, supplemented with properly balanced concentrate, cotton seed and citric pulp and housed at barns. The rations were in accordance with National Research Council (NRC, 2001) recommendations. During spring/summer the cows were kept in a rotational pasture system, supplemented with properly balanced concentrate. The heifers were kept on pasture under rotational management during spring/summer, and during fall/winter they received corn or sorghum silage, also supplemented with balanced concentrate. Cows and heifers had ad libitum access to fresh and mineral water.

The herd was vaccinated in accordance with the zoonotic calendar of the farm against major endemic diseases in the region and reproductive diseases (e.g. IBR, BVD, brucellosis, leptospirosis).

The reproductive management was conducted every 30 days, by ultrasound with a $7.5-\mathrm{MHz}$ linear transrectal transducer (Mindray DP-3300vet). The presence of corpus luteum (CL) was evaluated in all heifers. Cyclicity, postpartum and uterine condition were evaluated in cows with more than 30 days postpartum (DPP).

Cows with more than 30 DPP with good uterine condition (no uterine content, clean aspect) no lameness or clinical mastitis, and body condition score (BCS) equal to or greater than 2.5 (using a quarterpoint scale from 1 to 5 , where $1=$ emaciated and $5=$ obese) (FERGUSON et al., 1994), were involved in this study.

The cows were divided between two groups, as: group 1: TAI - those cows with no CL at ultrasound exam that were enrolled in a TAI protocol (CARDOSO et al., 2006). The TAI protocol was: Day 0: $2.0 \mathrm{mg}$ of estradiol benzoate $1.0 \mathrm{mg} / \mathrm{mL}$, i.m. $(2.0$ mL Estrogin ${ }^{\circledR}$; Farmavet, São Paulo, SP, Brazil) and insertion of progesterone $(\mathrm{P} 4)$ - releasing intravaginal device (CIDR ${ }^{\oplus} 1.9$ g P4; Pfizer Animal Health, São
Paulo, SP, Brazil); Day 7: $12.5 \mathrm{mg}$ dinoprost tromethamine, i.m. (2.5 mL Lutalyse ${ }^{\oplus}$; Pfizer Animal Health, São Paulo, SP, Brazil); Day 9: CIDR ${ }^{\bullet}$ removal and $1.0 \mathrm{mg}$ of estradiol cypionate, i.m. (0.5 mL ECP ${ }^{\star}$; Pfizer Animal Health, São Paulo, SP, Brazil); Day 11: TAI in all treated animals. Group 2: estrous synchronization - all cows that had CL and were treated with $25 \mathrm{mg}$ dinoprost tromethamine, i.m. (5.0 $\mathrm{mL}$ of Lutalyse ${ }^{\oplus}$; Pfizer Animal Health, São Paulo, SP, Brazil). After this, cows were visually observed for seven days and those that showed estrus behavior were inseminated twelve hours after detection.

Pregnancy diagnosis was performed in two steps: first, between 28 and 44 days post-AI, and second, reconfirmation for pregnancy status between 45 and 60 days after insemination, by transrectal ultrasound (Data not shown).

Cows that had a fetus with heartbeat in both exams were considered pregnant. The presence of pregnancy in the first exam and absence in the second was considered late embryonic loss. Pregnancy loss in cows confirmed pregnant in the second exam that returned to estrus showed abortion symptoms.

Data were collected from 997 cows and 371 heifers for three years. The following data were recorded: parity, season of calving and parturition. Season of calving was categorized as fall/winter or spring/summer. Parturition was categorized as abnormal (dystocia or abortion), or normal; finally, parity degree was categorized as 1, 2, 3 and $\geq 4$ ).

In this study, $\mathrm{RB}$ cows were considered those that failed to conceive from three or more regularly spaced services in the absence of detectable abnormalities, based on a study conducted by Yusuf et al. (2010). The mean number of IA per category was quantified in order to understand how many times each animal was inseminated. Repeat breeder cows and repeat breeder heifers were artificially inseminated around eight times per animal ( 7.83 vs. 7.75 ), while normal cows and normal heifers were artificially inseminated two times per animal ( 1.96 vs. 1.55$)$. 
The incidences of RB and factors relative to it were analyzed by logistic regression by PROC LOGISTIC of SAS, including the effects of season of calving, type of calving and parity. For this study, differences were considered significant when $\mathrm{P}<0.001$.

\section{Results}

The incidence of RB (considering cows that failed to conceive from three or more regularly spaced services) was higher in lactating dairy cows than in non-lactating heifers (24.5\% vs. $6.5 \%$; $\mathrm{P}<0.001$; Table 1). Thus, data from season of calving, type of calving and parity were only analyzed in lactating dairy cows.

\begin{tabular}{rc} 
Table 1 & \begin{tabular}{r} 
Incidence of Repeat breeder animals \\
in each category (cows and heifers) \\
evaluated from a crossbred dairy \\
\multicolumn{2}{c}{ herd - Centralina, MG - 2007-2009 }
\end{tabular} \\
\hline Animal Category (n) & Repeat Breeder (n) \\
\hline Cows (997) & $24.47 \%(244)$ \\
Heifers (397) & $6.47 \%(24)$ \\
P-value & 0.001 \\
\hline
\end{tabular}

There was a tendency $(\mathrm{P}=0.078$; Table 2$)$ of season of calving to influence the RB incidence. There was also a tendency of RB condition to be higher in cows that calved during spring/summer than in those calving during autumn/winter (26.7\% vs. $22.8 \%$; Table 2).

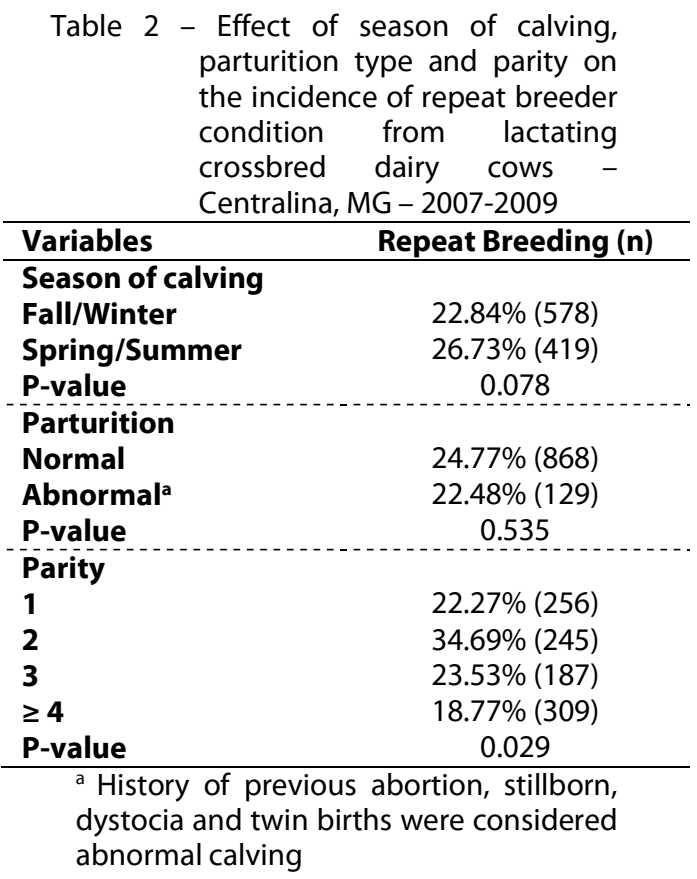

The parturition condition (normal vs. abnormal = dystocia, stillbirth) had no effects on RB incidence (P $=0.535$; Table 2). However, there was effect of parity on incidence of RB (first lactation $=22.3 \%$; second lactation $=34.7 \%$; third lactation $=23.5 \%$ and fourth or more lactation $=18.8 \% ; \mathrm{P}=0.029$; Table 2).

\section{Discussion}

The incidence of $\mathrm{RB}$ in lactating dairy cows varied among regions, environments, management and breeds. In this study it was higher in lactating dairy cows than in non-lactating heifers (Table 1); thus, RB condition in heifers was significantly lower than in lactating dairy cows. A study conducted by Bulman and Lamming (1978) showed that the incidence of RB in Friesian or Ayrshire dairy cows was $8.9 \%$. Gustafsson and Emanuelson (2002) related an incidence of $10 \%$ in dairy cattle. In a study with 22 Holstein - Friesian cows studied in Michigan, the incidence of $\mathrm{RB}$ ranged from $14.5 \%$ to $36.8 \%$ (BARTLETT et al., 1986).

In this experiment, a tendency of season of calving to influence the RB incidence was observed (Table 2), and $\mathrm{RB}$ condition seems to be higher in cows that calved during spring/summer than in those that calved during autumn/winter (Table 2). However, no significant difference about seasonal distribution of RB in a study with 22 Holstein - Friesian cows were found by Bartlett et al. (1986). On the other hand, when the season of calving was associated with risk of pregnancy, cows inseminated during summer and fall months were less likely to become pregnant than those inseminated during winter and spring; however, the season of calving was not associated with risk of pregnancy loss (SANTOS et al., 2009).

Still, Gustafsson and Emanuelson (2002) found that the risk of becoming RB was higher for cows inseminated during winter compared to those from other seasons, showing that external factors such as climate can influence that presence of RB in a herd. 
In this study, parturition condition (normal vs. abnormal) was evaluated, and no effect was observed in increasing $\mathrm{RB}$ condition. On the other hand, a positive correlation between risk of becoming a $\mathrm{RB}$ animal and dystocia (abnormal condition) were related by Gustafsson and Emanuelson (2002). In addition, a study conducted by Lafi et al. (1992) found that dystocia was the most significant risk factor directly associated with RB. This can be directly related to problems during parturition, as they lead to delay uterine involution, change ovarian functions, which causes lower conception rate, longer calving intervals and increases RB condition (MORROW et al., 1966).

In this experiment, parity degree significantly affected RB incidence. Cows from second parity probably suffered more with negative energy balance and this affected their reproductive efficiency, increasing the incidence of RB. In agreement with the results of this study, a correlation between parity and incidence of RB was observed by Yusuf et al. (2010), who found higher incidence of this condition in cows from first parity (19.4\%) when compared to second and third parity (12.2\% and $9.8 \%$, respectively). A higher incidence of RB in the first lactation may have been due to a high incidence of abnormal resumption of ovarian cycles in first-lactation cows (TAYLOR et al., 2003).

\section{References}

AYALON, N. A review of embryonic mortality in cattle. Journal of Reproduction \& Fertility, v. 54, n. 2, p. 483493, 1978. doi: 10.1530/jrf.0.0540483.

BAGE, R.; GUSTAFSSON, H.; LARSSON, B.; FORSBERG, M.; RODRÍGUEZ-MARTÍNEZ, H. Repeat breeding in dairy heifers: follicular dynamics and estrous cycle characteristics in relation to sexual hormone patterns. Theriogenology, v. 57, n. 9, p. 2257-2269, 2002. doi: 10.1016/S0093-691X(02)00840-3.

BARTLETT, P. C.; KIRK, J. H.; MATHER, E. Repeated insemination in Michigan Holstein-Fresian cattle:
A higher risk to be $\mathrm{RB}$ in primiparous cows when compared with multiparous cows was affirmed by Gustafsson and Emanuelson (2002), reflecting the difficulties of first parity cows to cope with the metabolic demands necessary for lactation and reproduction. On the other hand, no significant difference in the incidence of $\mathrm{RB}$ in primiparous cows compared to multiparous cows was demonstrated in a study developed by Brooks (1998). Still, it is hard to know the cause of $R B$, but cows submitted to a stressful situation can become RB, because the function of the hypothalamus-pituitary-gonadal axis may be disrupted during stress (DOBSON; SMITH, 2000).

In conclusion, the incidence of repeat breeder condition was greater in lactating crossbred dairy cows than in heifers. Moreover, the presence of repeat breeder cows was higher in those from second parity group when compared to those from first, third and fourth parity group. On the other hand, parturition condition (normal versus abnormal) did not influence the appearance of repeat breeder cows in the herd.

\section{Acknowledgments}

The authors acknowledge that all the people who worked at the farm were enrolled in the experiment.

incidence, descriptive epidemiology and estimated economic impact. Theriogenology, v. 26, n. 3, p. 309-322, 1986. doi: 10.1016/0093-691X(86)90150-0.

BROOKS, G. Fertility of repeat breeder cows in subsequent lactations. Veterinary Record, v. 143, n. 22, p. 615-616, 1998. doi: 10.1136/vr.143.22.615.

BULMAN, D. C.; LAMMING, G. E. Milk progesterone levels in relation to conception, repeat breeding and factors influencing acyclicity in dairy cows. Journal of 
Reproduction and Fertility, v. 54, n. 2, p. 447-458, 1978. doi: 10.1530/jrf.0.0540447.

CARDOSO, B. L.; PESCARA, J. B.; VASCONCELOS, J. L. M. Protocolos de inseminação artificial em tempo fixo para vacas mestiças leiteiras. Acta Scientiae Veterinariae, v. 34, p. $428,2006$.

DOBSON, H.; SMITH, R. F. What is the stress, and how does it affect reproduction? Animal Reproduction Science, v. 60-61, p. 743-752, 2000. doi: 10.1016/S03784320(00)00080-4.

FERGUSON, J. D.; GALLIGAN, D. T.; THOMSEN, N. Principal descriptors of body condition score in Holstein cows. Journal of Dairy Science, v. 77, n. 9, p. 2695-2703, 1994. doi: 10.3168/jds.S0022-0302(94)77212-X.

GILBERT, R. O.; SHIN, S. T.; GUARD, C. L.; ERB, H. N.; FRAJBLAT, M. Prevalence of endometritis and its effects on reproductive performance of dairy cows. Theriogenology, v. 64, n. 9, p. 1879-1888, 2005. doi: 10.1016/j.theriogenology.2005.04.022.

GUSTAFSSON, H. Studies on follicular dynamics and hormonal asynchrony around ovulation as a potential cause of repeat breeding. Reproduction in Domestic Animals, v. 33, n. 3-4, p. 139-140, 1998. doi: 10.1111/j.1439-0531.1998.tb01331.x.

GUSTAFSSON, H.; EMANUELSON, U. Characterisation of the repeat breeding syndrome in Swedish dairy cattle. Acta Veterinaria Scandinavica, v. 43, n. 2, p. 115-125, 2002. doi: 10.1186/1751-0147-43-115.

HALLAP, T.; NAGY, S.; JAAKMA, Ü.; JOHANNISSON, A.; RODRÍGUEZ-MARTÍNEZ, H. Usefulness of a triple flurochrome combination Merocyanine 540/Yo-Pro 1/Hoechst 33342 in assessing membrane stability of viable frozen-thawed spermatozoa from Estonian Holstein AI bulls. Theriogenology, v. 65, n. 6, p. 1122-1136, 2006. doi: 10.1016/j.theriogenology.2005.07.009.

HEUWIESER, W.; OLTENACU, P. A.; LEDNOR, A. J.; FOOTE, R. H. Evaluation of different protocols for prostaglandin synchronization to improve reproductive performance in dairy herds with low estrus detection efficiency. Journal of Dairy Science, v. 80, n. 11, p. 27662774, 1997. doi: 10.3168/jds.S0022-0302(97)76239-8.

KIMURA, M.; NAKAO, T.; MORIYOSH, M.; KAWATA, $\mathrm{K}$. Luteal phase deficiency as a possible cause of repeat breeding in dairy cows. British Veterinary Journal, v. 143, n. 6, p. 560-566, 1987. doi: 10.1016/0007-1935(87)90047-9.

LAFI, S. Q.; KANEENE, J. B. Epidemiological and economic study of the repeat breeder syndrome in Michigan dairy cattle. I. Epidemiological modeling. Preventive Veterinary Medicine, v. 14, n. 1-2, p. 87-98, 1992. doi: 10.1016/0167-5877(92)90087-V.

LAFI, S. Q.; KANEENE, J. B.; BLACK, J. R.; LLOYD, J. W. Epidemiological and economic study of the repeat breeder syndrome in Michigan dairy cattle. II. Economic modeling. Preventive Veterinary Medicine, v. 14, n. 1-2, p. 99-114, 1992. doi: 10.1016/0167-5877(92)90088-W.

LÓPEZ-GATIUS, F.; YANIZ, J. L.; SANTOLARIA, P.; MURUGAVEL, K.; GUIJARRO, R.; CALVO, E.; LÓPEZBÉJAR, M. Reproductive performance of lactating dairy cows treated with cloprostenol at the time of insemination. Theriogenology, v. 62, n. 3-4, p. 677-689, 2004. doi: 10.1016/j.theriogenology.2003.11.014.

MANN, G. E.; LAMMING, G. E. Relationship between maternal endocrine environment, early embryo development and inhibition of the luteolytic mechanism in cows. Reproduction, v. 121, n. 1, p. 175-180, 2001. doi: 10.1530/rep.0.1210175.

MORRELL, J. M. Update on semen technologies for animal breeding. Reproduction in Domestic Animals, v. 41, n. 1, p. 63-67, 2006. doi: 10.1111/j.1439-0531.2006.00621.x.

MORROW, D. A.; ROBERTS, S. J.; MCENTEE, K.; GRAY, H. G. Postpartum ovarian activity and uterine involution in dairy cattle. Journal of the American Veterinary Medicine Association, v. 149, p. 1596-1609, 1966.

MOSS, N.; LEAN, I. J.; REID, S. W. J.; HODGSON, D. R. Risk factors for repeat-breeder syndrome in New South Wales dairy cows. Preventive Veterinary Medicine, v. 54, n. 2, p. 91-103, 2002. doi: 10.1016/S0167-5877(02)00016-8.

NATIONAL RESEARCH COUNCIL (NRC). Nutrient requirements of dairy cattle. $7^{\text {th }}$ ed. Washington: National Academy Press, 2001. 408 p.

O'FARRELL, K. J.; LANGLEY, O. H.; HARTIGAN, P. J.; SREENAN, J. M. Fertilization and embryonic survival rates in dairy cows culled as repeat breeders. Veterinary Record, v. 112, n. 5, p. 95-97, 1983. doi: 10.1136/vr.112.5.95.

PÉREZ-MARÍN, C. C.; ESPAÑA, F. Oestrus expression and ovarian function in repeat breeder cows, monitored by 
ultrasonography and progesterone assay. Reproduction in Domestic Animals, v. 42, n. 5, p. 449-456, 2007. doi: 10.1111/j.1439-0531.2006.00805.x.

PETERS, A. R. Embryonic mortality in the cow. Animal Breeding Abstracts, v. 64, p. 587-598, 1996.

PURSLEY, J. R.; SILCOX, R. W.; WILTBANK, M. C. Effect of time of artificial insemination on pregnancy rates, calving rates, pregnancy loss, and gender ratio after synchronization of ovulation in lactating dairy cows. Journal of Dairy Science, v. 81, n. 8, p. 2139-2144, 1998. doi: 10.3168/jds.S0022-0302(98)75790-X.

SANTOS, J. E. P.; RUTIGLIANO, H. M.; SÁ FILHO, M. F. Risk factors for resumption of postpartum estrous cycles and embryonic survival in lactating dairy cows. Animal Reproduction Science, v. 110, n. 3-4, p. 207-221, 2009. doi: 10.1016/j.anireprosci.2008.01.014.
TAYLOR, V. J.; BEEVER, D. E.; BRYANT, M. J.; WATHES, D. C. Metabolic profiles and progesterone cycles in first lactation dairy cows. Theriogenology, v. 59, p. 1661-1677, 2003. doi: 10.1016/S0093-691X(02)01225-6.

VILLARROEL, A.; MARTINO, A.; BONDURANT, R. H.; DĖLETANG, F.; SISCHO, W. M. Effect of post-insemination supplementation with PRID on pregnancy in repeat-breeder Holstein cows. Theriogenology, v. 61, n. 7-8, p. 1513-1520, 2004. doi: 10.1016/j.theriogenology. 2003.09.001.

YUSUF, M.; NAKAO, T.; RANASINGHE, R. M. S. B. K.; GAUTAM, G.; LONG, S. T.; YOSHIDA, C.; KOIKE, k.; HAYASHI, A. Reproductive performance of repeat breeders in dairy herd. Theriogenology, v. 73, n. 9, p. 1220-1229, 2010.2 doi: 10.1016/j.theriogenology.2010.01.016. 